International Journal of Power Electronics and Drive System (IJPEDS)

Vol. 10, No. 4, December 2019, pp. 2238 2244

ISSN: 2088-8694, DOI: 10.11591/ijpeds.v10.i4.pp2238-2244

2238

\title{
Proportional resonant current controller strategy in inverter application
}

\author{
S. Salimin, A.F.M. Noor, S. A. Jumaat \\ Green and Sustainable Energy Focus Group (GSEnergy), Faculty of Electrical and Electronic Engineering, Universiti \\ Tun Hussein Onn Malaysia (UTHM), Malaysia
}

\begin{tabular}{l}
\hline Article Info \\
\hline Article history: \\
Received Apr 17, 2019 \\
Revised Jun 20, 2019 \\
Accepted Jul 24, 2019 \\
\hline
\end{tabular}

\section{Keywords:}

Controller

Harmonic distortion

Nonlinear load

Proportional resonant

\begin{abstract}
This paper presents the method of proportional resonant current controller strategy in inverter system application. In this study, the mathematical modelling of the controller is shown in detail. This is important for the modelling in Matlab Simulink. Nowadays, the decrement of power quality is easily found in this inverter system where inverter extensively used as interface circuits. To solve this problem, proportional resonant current controller is the solution. At resonant frequency, this controller has infinite gain which ensures a zero steady-state error in a stationary frame. This will result in minimized load current distortion as well as the harmonic contents. At the end, simulation result shows when using PR current controller, the unwanted harmonics injection are much reduced.
\end{abstract}

Copyright (C) 2019 Institute of Advanced Engineering and Science. All rights reserved.

\section{Corresponding Author:}

Suriana binti Salimin, Green and Sustainable Energy Focus Group (GSEnergy),

Faculty of Electrical and Electronic Engineering,

Universiti Tun Hussein Onn Malaysia,

86400 Parit Raja, Batu Pahat, Johor, Malaysia.

Email: suriana@uthm.edu.my

\section{INTRODUCTION}

Nowadays, renewable energy sources such as wind, solar, hydraulic in power generation has become more important as energy consumption increases. The output current from the free energy sources are in direct current [1]. In order to convert the current into alternative current for transmission, inverter are used to convert and interface the current waveform. Inverter is usually pulse-width modulated. It occurs at a high switching frequency, either current controlled or voltage controlled and uses whether a linear or can be nonlinear control algorithm as well [2]. This synthesis method of inverter will produce harmonics spectra and as well as the non-linear loads that used in distribution.

For non-linear loads, its current waveform is not proportional to the voltage. This is different for linear loads where the current is proportional to the applied voltage [3]. Today, for most power networks, the major source of unwanted harmonic generations are from non-linear loads. It can degrade the power quality and cause resonance problems [4]. Rectifiers specifically which are broadly used as power electronic component to interface the system is one of the reason for degradation of power quality. For many domestic appliances which has rectifiers in its switched mode power supplies can degrade the quality of voltage supply [5-6]. One way to improve the power quality is by using filters, a power electronic device that has excellent task for performance filtering. Filters can be used either as a voltage controlled source or a current controlled source [7-11]. Two types of filter which is vital to consider for harmonics cancellation is the shunt and series active filter. Both have their own purposes; to inject currents so that it cancels harmonic currents directly and compensates distortion of voltage caused by non-linear loads respectively [12]. The performance of these filters are evaluated on the current control and the harmonic reference generation system. 
For control system, the conventional proportional integral (PI) controller is easy to be implemented. However, one common drawback of PI controllers is they cannot track non direct current references without errors between the reference and output currents getting out from the filters [13]. The system will be unstable when the attenuation and resonant frequency of the filter varies significantly [14]. Thus, proportional resonant (PR) controller is used to reduce and even eliminate these harmonics disturbances. The characteristic of PR controller which has infinite gain at the resonant frequency will ensure zero steadystate error in a stationary frame. As a result, it minimize load current distortion, reduce unwanted harmonics, and will have better time domain response [15-25]. The connected filter is use to filter the inverter's switching frequencies [26].

This paper presents the method of proportional resonant current controller strategy in inverter system application. In this study, the mathematical modelling of the controller is shown in the next section. Previous researches in inverter application is discussed in brief in the following section. At the end, simulation result shows when using PR current controller, the unwanted harmonics injection are much reduced.

\section{PROPORTIONAL RESONANT CONTROLLER}

Figure 1 below shows the block diagram in a system using PR current controller. There are basically three block systems in the figure which are the controller block, the inverter block and the filter block. The current reference, $\mathrm{I}_{\mathrm{i}}{ }^{*}$ will be compared with the output current $\mathrm{I}_{\mathrm{i}}$ coming out after the filtering process. It is the resultant error which then be the input for controlling system.

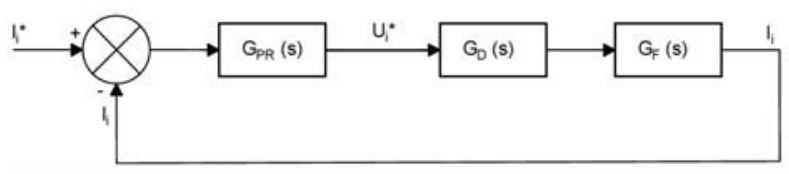

Figure 1. Block diagram of inverter system with PR current controller [27]

From the figure, the PR current controller $\mathrm{G}_{\mathrm{PR}}(\mathrm{s})$ is represented by:

$$
G_{P R}(s)=K_{P}+K_{I} \frac{s}{s^{2}+\omega_{0}^{2}}
$$

where, $K_{P}$ is the proportional gain term, $K_{I}$ is the Integral Gain term and $\omega_{o}$ is the resonant frequency. The resonant term will basically provide infinite gain at the system frequency, $\omega_{o}$ and at other frequencies, there will not be occurring any phase shift and gai $[28,29]$. The $K_{P}$ term controls the system dynamic such as gain and phase margins as well as its bandwidth. Despite all this, (1) can allow stability problems to arise because of the infinite gain. Therefore, the control system can be made non ideal. For this to happen, damping is introduced. It is shown in (2) below;

$$
G_{P R}(s)=K_{P}+K_{I} \frac{2 \omega_{c} s}{s^{2}+2 \omega_{c} s+\omega_{0}^{2}}
$$

where, $\omega_{c}$ is the bandwidth around the system frequency of $\omega_{o}$. From the equation, the gain of the controller at the system frequency $\omega_{o}$ is now restricted. Nevertheless, it is still large enough to give only a slightly small steady state error. The equation is actually making the controller more reliable in digital systems due to their rigorous limitation [30]. For simulating in Matlab purposes, based on (1), by using the Tustin transformation, the analogue equation above is changed to the $\mathrm{z}$ domain known as the discrete function. This is done by substituting $s$ with $\frac{2}{T} \frac{1-z^{-1}}{1+z^{-1}}$. Based on that, it is then transformed to;

$$
\begin{aligned}
& G_{P R}(z)=K_{P}+K_{R} \frac{\frac{21-z^{-1}}{T_{1}+z^{-1}}}{\left(\frac{21-z^{-1}}{T_{1}+z^{-1}}\right)^{2}+\omega_{o}^{2}} \\
& G_{P R}(z)=\frac{K_{P}\left[\left(\frac{21-z^{-1}}{T_{1}+z^{-1}}\right)^{2}+\omega_{o}^{2}\right]+K_{R}\left(\frac{21-z^{-1}}{T_{1}+z^{-1}}\right)}{\left(\frac{21-z^{-1}}{T_{1}+z^{-1}}\right)^{2}+\omega_{o}^{2}}
\end{aligned}
$$

Proportional resonant current controller strategy in inverter application (S. Salimin) 


$$
\begin{aligned}
& G_{P R}(z)=\frac{K_{P}\left[\left(\frac{4}{T^{2}}\right)\left(\frac{1-2 z^{-1}+z^{-2}}{1+2 z^{-1}+z^{-2}}\right)+\omega_{0}^{2}\right]+\frac{2 K_{R}}{T}\left(\frac{1-z^{-1}}{1+z^{-1}}\right)}{\left(\frac{4}{T^{2}}\right)\left(\frac{1-2 z^{-1}+z^{-2}}{1+2 z^{-1}+z^{-2}}\right)+\omega_{0}^{2}} \\
& G_{P R}(z)=\frac{\left(\frac{4 K_{P}}{T^{2}}\right)\left(\frac{1-2 z^{-1}+z^{-2}}{1+2 z^{-1}+z^{-2}}\right)+K_{P} \omega_{0}^{2}+\frac{2 K_{R}}{T}\left(\frac{1-z^{-1}}{1+z^{-1}}\right)}{\frac{4\left(1-2 z^{-1}+z^{-2}\right)+T^{2} \omega_{0}^{2}\left(1+2 z^{-1}+z^{-2}\right)}{T^{2}\left(1+2 z^{-1}+z^{-2}\right)}}
\end{aligned}
$$

In order to get a simpler transfer function, some adjustments are made. This is shows as below:

$$
\begin{aligned}
& G_{P R}(z)=\frac{\left(\frac{4 K_{P}}{T^{2}}\right)\left(\frac{1-2 z^{-1}+z^{-2}}{1+2 z^{-1}+z^{-2}}\right)+K_{P} \omega_{0}^{2}\left(\frac{T^{2}\left(1+2 z^{-1}+z^{-2}\right)}{T^{2}\left(1+2 z^{-1}+z^{-2}\right)}\right)+\frac{2 K_{R} T}{T^{2}}\left(\frac{1-z^{-2}}{1+2 z^{-1}+z^{-2}}\right)}{\frac{4\left(1-2 z^{-1}+z^{-2}\right)+T^{2} \omega_{0}^{2}\left(1+2 z^{-1}+z^{-2}\right)}{T^{2}\left(1+2 z^{-1}+z^{-2}\right)}} \\
& =\frac{4 K_{P}\left(1-2 z^{-1}+z^{-2}\right)+K_{P} \omega_{0}^{2} T^{2}\left(1+2 z^{-1}+z^{-2}\right)+2 K_{R} T\left(1-z^{-2}\right)}{4\left(1-2 z^{-1}+z^{-2}\right)+T^{2} \omega_{0}^{2}\left(1+2 z^{-1}+z^{-2}\right)} \\
& =\frac{4 K_{P}-8 K_{P} z^{-1}+4 K_{P} z^{-2}+K_{P} \omega_{0}^{2} T^{2}+2 K_{P} \omega_{0}^{2} T^{2} z^{-1}+K_{P} \omega_{0}^{2} T^{2} z^{-2}+2 K_{R} T-2 K_{R} T z^{-2}}{4-8 z^{-1}+4 z^{-2}+T^{2} \omega_{0}^{2}+2 T^{2} \omega_{0}^{2} z^{-1}+T^{2} \omega_{0}^{2} z^{-2}} \\
& =\frac{\left(4 K_{P}+K_{P} \omega_{0}^{2} T^{2}+2 K_{R} T\right)+\left(2 K_{P} \omega_{0}^{2} T^{2}-8 K_{P}\right) z^{-1}+\left(4 K_{P}+K_{P} \omega_{0}^{2} T^{2}-2 K_{R} T\right) z^{-2}}{\left(4+T^{2} \omega_{0}^{2}\right)+\left(2 T^{2} \omega_{0}^{2}-8\right) z^{-1}+\left(4+T^{2} \omega_{0}^{2}\right) z^{-2}}
\end{aligned}
$$

By dividing the nominator and the denominator of the transfer function in (4) above with $\left(4+T^{2} \omega_{0}^{2}\right)$, the discrete form becomes:

$$
G_{P R}(z)=\frac{\frac{\left(4 K_{P}+K_{P} \omega_{0}^{2} T^{2}+2 K_{R} T\right)}{\left(4+T^{2} \omega_{0}^{2}\right)}+\frac{\left(2 K_{P} \omega_{0}^{2} T^{2}-8 K_{P}\right)}{\left(4+T^{2} \omega_{0}^{2}\right)} z^{-1}+\frac{\left(4 K_{P}+K_{P} \omega_{0}^{2} T^{2}-2 K_{R} T\right)}{\left(4+T^{2} \omega_{0}^{2}\right)} z^{-2}}{1+\frac{\left(2 T^{2} \omega_{0}^{2}-8\right)}{\left(4+T^{2} \omega_{0}^{2}\right)} z^{-1}+z^{-2}}
$$

To simplify the above equation, it can be re-written as:

$$
G_{P R}(z)=\frac{b_{0}+b_{1} z^{-1}+b_{2} z^{-2}}{1+a_{1} z^{-1}+a_{2} z^{-2}}
$$

where;

$$
\begin{aligned}
& \mathrm{b}_{\mathrm{o}}=\frac{\left(4 \mathrm{~K}_{\mathrm{P}}+\mathrm{K}_{\mathrm{P}} \omega_{0}^{2} \mathrm{~T}^{2}+2 \mathrm{~K}_{\mathrm{R}} \mathrm{T}\right)}{\left(4+\mathrm{T}^{2} \omega_{0}^{2}\right)} \\
& \mathrm{b}_{1}=\frac{\left(2 \mathrm{~K}_{\mathrm{P}} \omega_{0}^{2} \mathrm{~T}^{2}-8 \mathrm{~K}_{\mathrm{P}}\right)}{\left(4+\mathrm{T}^{2} \omega_{0}^{2}\right)} \\
& \mathrm{b}_{2}=\frac{\left(4 \mathrm{~K}_{\mathrm{P}}+\mathrm{K}_{\mathrm{P}} \omega_{0}^{2} \mathrm{~T}^{2}-2 \mathrm{~K}_{\mathrm{R}} \mathrm{T}\right)}{\left(4+\mathrm{T}^{2} \omega_{0}^{2}\right)} \\
& \mathrm{a}_{1}=\frac{\left(2 \mathrm{~T}^{2} \omega_{0}^{2}-8\right)}{\left(4+\mathrm{T}^{2} \omega_{0}^{2}\right)} \\
& \mathrm{a}_{2}=1
\end{aligned}
$$

$K_{P}$ and $K_{R}$ is the proportional gain and the resonance gain respectively, $\mathrm{T}$ is the sampling time and $\omega_{o}$ is the system frequency in $\mathrm{rad} / \mathrm{sec}$. With the resonance part added to the proportional controller, the system steady state error can be much reduced or nearly eliminated. Substituting T with $50 \mu \mathrm{s}$ and $\omega_{o}$ with $2 \pi \times 50 \mathrm{~Hz}$, the optimum gains for this control technique can be obtained by trial and error tuning. Figure 2 is the transformation of equation [6] that is modelled in Matlab Simulink. It is the resulting output signal that is used in the inverter switching process. 


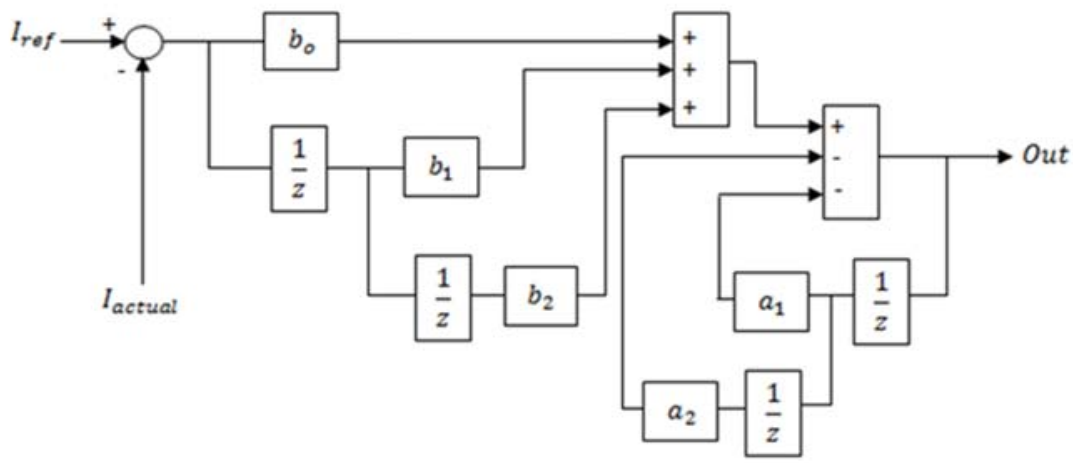

Figure 2. The parameters in the PR current controller system

\section{PROPORTIONAL RESONANT CONTROLLER IN INVERTER APPLICATION}

Inverter systems are very essential as a power generating method. Furthermore, the number of these inverter systems that are being connected to the grid is climbing. A paper by [31] has review the three phase inverters control to compensate an unbalanced load. Effectiveness of proportional resonant controller has been proved by many researchers where some of them can be found in [32-37]. To decrease the bad effects on the power quality, it is very important to maintain the harmonics injected by these inverters under certain limit. PR controller provides high gain at a certain resonant frequency and almost no gain exists at the other frequencies. Thus, it exhibits good transient response over the conventional PI controller when system subjected to load disturbance. The better performance is obtained using harmonic compensator along with the modelled PR controller. PR controller exhibits good transient response over the conventional PI controller when system subjected to load disturbance and better performance is obtained using harmonic compensator along with the modelled PR controller [38].

From [35], the inverter output current waveform are in acceptable sinusoidal shape when the system uses a PR current controller, as seen in the simulation results shown in Figure 3 It has still a steady state error but of small value. This is because of using a non-ideal PR controller mentioned earlier to avoid stability problems in the controller.

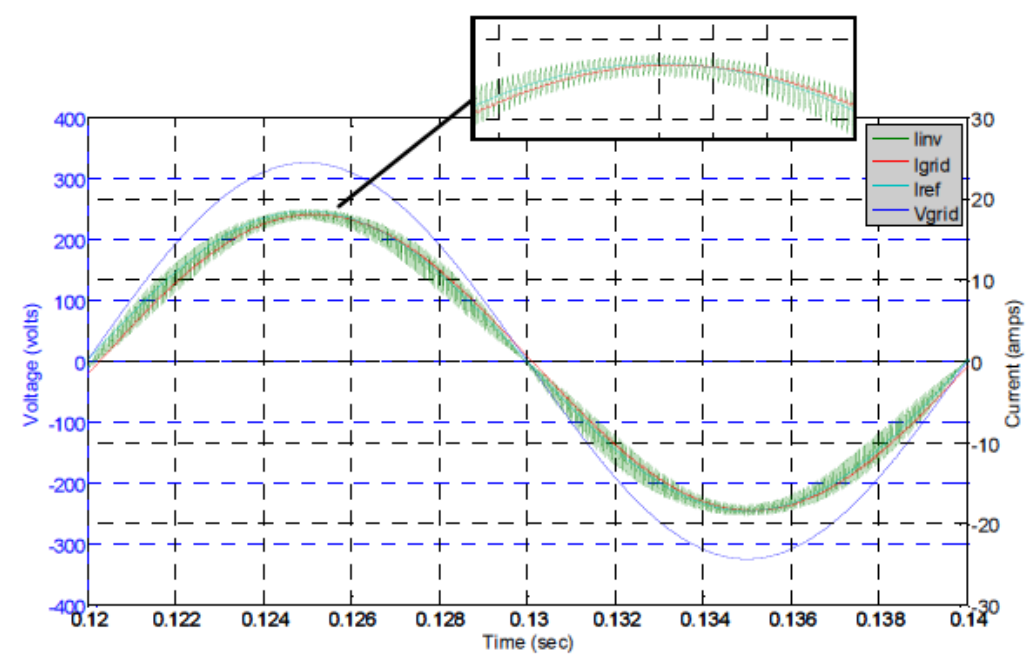

Figure 3. Grid voltage, grid current, reference current, inverter current in simulation with PR controller [35] 
Figure 4 shows that the original harmonic spectrum without using PR current controller result simulation. It can be seen a big percentage number of amplitude in the $3^{\text {rd }}, 5^{\text {th }}$, and $7^{\text {th }}$ frequency. Whilst in Figure 5, it shows the grid current harmonic profiles when PR controller is used. From the figure, it also noticeable that the $1^{\text {st }}$ harmonic of the grid current achieved $100 \%$. This means the value is as expected. In addition, the $3 \mathrm{rd}$, 5th and 7 th harmonics reached around only $5 \%$ of current amplitude which shows better performance in term of unwanted harmonics injection.

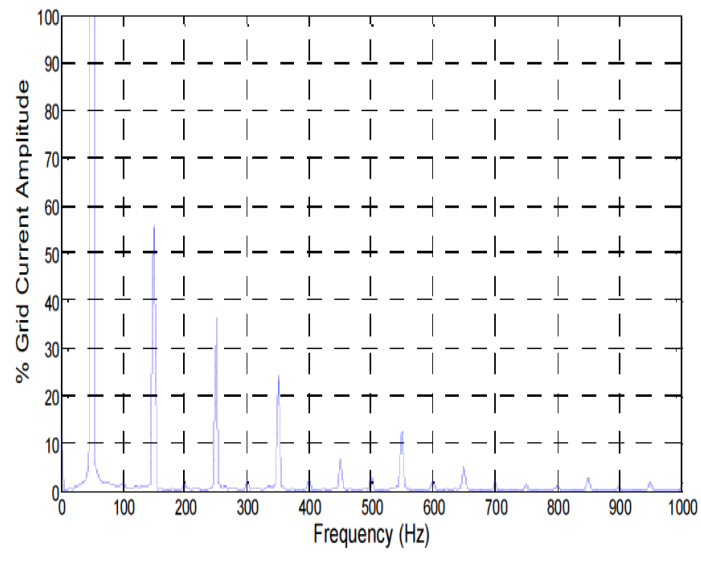

Figure 4. Harmonic spectrum without PR current controller [35].

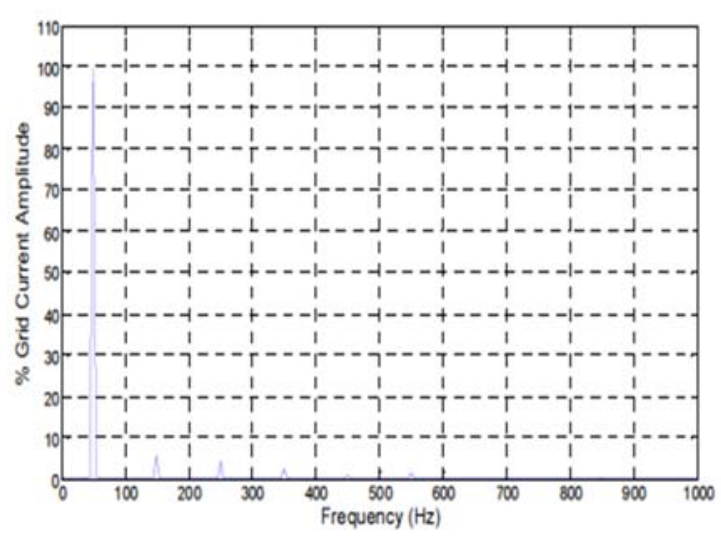

Figure 5. Harmonic Spectrum with PR current controller [35]

\section{CONCLUSION}

This paper has presented a method of proportional resonant controller used in inverter application. Mathematical function and modelling in Matlab of the PR controller is shown. An overview of this controller in inverter application has been done where in one of the research, using PR controller has reduce the error of fundamental current to zero, while 3rd, 5th, 7th harmonics in grid current also improved to around 5\%. As a conclusion, from the review, it shows the good merit of using proportional resonant controller in inverter application.

\section{ACKNOWLEDGEMENTS}

The authors would like to acknowledge the Research Management Center (RMC), Universiti Tun Hussein Onn Malysia (UTHM), Batu Pahat, Johor, Malaysia for granting the Tier 1 (H157) Grant and and support the publication.

\section{REFERENCES}

[1] F. A. Silva, "Advanced DCVAC Inverters: Applications in Renewable Energy (Luo, F.L. and Ye, H.; 2013) [Book News]," in IEEE Industrial Electronics Magazine, vol. 7, no. 4, pp. 68-69, Dec. 2013.

[2] J. A. Yeamans, "Intrinsic Harmonics of Idealized Inverter PWM Systems" United States: Cleveland, 1976. 1-7.

[3] Perra and M. Suri, "Inverter application for non-linear loads," Proceedings of the Sixth Annual Battery Conference on Applications and Advances, Long Beach, CA, USA, 1991, pp. 1-10.

[4] R. Madhu, M. N. Dinesh, B. M. Ravitheja, "Design of shunt hybrid active power filter (SHAPF) to reduce harmonics in AC side due to Non-linear loads," International Journal of Power Electronics and Drive Systems (IJPEDS). vol. 9(4), pp. 1926-1936.

[5] H-S.S. Song, R. Keil, P. Mutschler, J. Weem, K. Nam, “Advanced Control Scheme for a Single-Phase PWM Rectifier in Traction Applications," IAS 2003, pp. $1558-1565$

[6] M. Liserre, F. Blaabjerg, and S. Hansen, "Design and control of an LCL-filter based active rectifier," IEEE Trans. on Ind. App., vol. 38, no. 2 Sept./Oct. 2001, pp. 299-307.

[7] Hambley, Allan R. Electrical Engineering: Principles and Applications, 2nd ed, Upper Saddle River, NJ: Prentice Hall, 2002. pp. 3-5.

[8] P. Mattavelli "A Closed-Loop Selective Harmonic Compensation for Active Filters," IEEE Trans. on Ind. App., vol. 37 , no. 1 , pp. $81-89,2001$. 
[9] D. N. Zmood, D. G. Holmes, "Stationary Frame Current Regulation of PWM Inverters with Zero Steady-State Error," IEEE Trans. on Power Electr., vol. 18, no. 3, pp. 814 - 822, May 2003.

[10] Teodorescu, R., Blaabjerg, F., Liserre. M., Borup, U., "A New Control Structure for Grid-Connected PV Inverters with Zero Steady-State Error and Selective Harmonic Compensation," Proceedings of APEC'04, Anaheim, CA.

[11] R. Teodorescu, F. Blaabjerg, U. Borup, M. Liserre, "A New Control Structure for Grid-Connected LCL PV Inverters with Zero Steady-State Error and Selective Harmonic Compensation,” APEC’04 Nineteenth Annual IEEE Conference, California, 2004.

[12] Guo Xiaoqiang, Zhao Qinglin and Wu Weiyang "A Single-Phase Grid- Connected Inverter System with Zero Steady-State Error," in CES/IEEE 5th International Power Electronics and Motion Control Conference, vol. 1, pp. 1-5, Aug. 2006.

[13] Wang, Liuping. PID and Predictive Control of Electrical Drives and Power Supplies Using MATLAB/Simulink.

[14] C. Liu and J. -S. Lai, "Low frequency current ripple reduction technique with active control in a fuel cell power system with inverter load," in IEEE Transactions on Power Electronics, vol. 22, no. 4, pp. 1429-1436, July 2007.

[15] S. Eren, A. Bakhshai and P. Jain, "Control of Three-Phase Voltage Source Inverter for Renewable Energy Applications," IEEE Proceedings, 2011.

[16] M. Kazmierkowski, R. Krishnan, F. Blaabjerg, Control in Power Electronics: Selected Problems, Academic Press Series in Engineering, 2002.

[17] X. Yuan, W. Merk, H. Stemmler, J. Allmeling, "Stationary-Frame Generalized Integrators for Current Control of Active Power Filters with Zero Steady-State Error for Current Harmonics of Concern Under Unbalanced and Distorted Operating Conditions," IEEE Trans. on Ind. App., vol. 38, no.2, pp.523 - 532, 2002.

[18] M. Liserre, R. Teodorescu, Z. Chen, "Grid Converters and their Control in Distributed Power Generation Systems," IECON 2005, 2005.

[19] M. Ciobotaru, R. Teodorescu, F. Blaabjerg, "Control of a Single-Phase PV Inverter,” EPE2005, Dresden, 2005.

[20] IEEE 1547 Standard for Interconnecting Distributed Resources with Electric Power Systems.

[21] F. Blaabjerg. R. Teodorescu. M. Liserre, and A. V. Timbus, "Overview of Control and Grid Synchronization for Distributed Power Generation Systems," IEEE Transactions on Industrial Electronics, vol. 53, no. 5, pp. 13981409 , Oct 2006.

[22] IEEE Standard 1547-2003 "IEEE Standard for Interconnecting Distributed Resources with Electric Power Systems," 2003.

[23] H. Akagi, E.H. Watanabe, and M. Aredas, Instantaneous power theory and applications to power conditioning, Hoboken NJ, Wiley, 2007.

[24] S. Salimin, A.A. Bakar, M. Armstrong, "Low order harmonics improvement of a single grid connected inverter system under PR control technique," ARPN Journal of Engineering and Applied Sciences, vol. 10(19), pp. 8601-8605, 2015.

[25] B. K. Jagadish and B. Banakara, "Current mode proportional resonant controlled multi input-SEPIC-re-boostsystem," International Journal of Power Electronics and Drive Systems (IJPEDS), vol. 10(2), pp. 682-689, 2019.

[26] V. Pradeep, A. Kolwalkar, R. Teichmann, "Optimized Filter Design for IEEE 519 Compliant Grid Connected Inverters," IICPE 2004, Mumbai, India, 2004.

[27] R. Teodorescu, M. Liserre, P. Rodriguez, "Grid Converters for Photovoltaic and Wind Power Systems," USA: Wiley, 2011.

[28] K. C. Chen, S. Salimin, S. A. Zulkifli, R. Aziz, "Single phase inverter system using proportional resonant current control," International Journal of Power Electronics and Drive Systems (IJPEDS), vol. 8(4), pp. 1913-1918, 2017

[29] D. N. Zmood, D. G. Holmes, "Stationary Frame Current Regulation of PWM Inverters with Zero Steady-State Error," IEEE Transactions on Power Electronics, vol. 18, no. 3, May 2003.

[30] R. Aboelsaud, A. Ibrahim and A. G. Garganeev, "Review of three-phase inverters control for unbalanced load compensation," International Journal of Power Electronics and Drive Systems (IJPEDS), vol. 10, no. 1, pp.242-255, 2019.

[31] X. Su, K. Zhou, W. Zhu and L. Zhu, "Proportional-resonant current control of single-phase grid-tied PV inverter system," CICED 2010 Proceedings, Nanjing, 2010, pp. 1-4.

[32] Zhang Jun- Li, Li Yu- Ren, Wang Peng, Liang Bo and FU Long- Fei, "The Analysis and Implementation of Proportional Resonant Control Algorithm-based Pwm Inverter Imbalanced Grid-connected,” Journal of Software Engineering, vol. 9, no. 3, pp. 548-560, 2015.

[33] J. F. Ardashir, M. Sabahi, S. H. Hosseini, E. Babaei, G. Gharehpetian, "An Improved Grid Connected Transformerless Inverter With Proportional Resonant Controller,” Spring, vol.15(1), pp. 30-38, 2017.

[34] L. Herman, I. Papic and B. Blazic, "A proportional-resonant current controller for selective harmonic compensation in hybrid active power filter," Power Delivery, IEEE Transactions on, vol.29, pp. 2055-2065, 2014.

[35] Teodorescu, F. Blaabjerg, M. Liserre, and P. Loh, "Proportional resonant controllers and filters for grid-connected voltage-source converters," Electric Power Applications, IEE Proceedings, vo1. 153, no. 5, pp.750-762, Sep 2006.

[36] D. Zammit, C. Spiteri Staines, M. Apap "Comparison between PI and PR Current Controllers in Grid Connected PV Inverters," International Journal of Electrical, Computer, Energetic, Electronic and Communication Engineering, vol. 8, no, 2, 2014.

[37] S. A. Zulkifli, S. Salimin, A. Khairi and A. Rahman, "Investigation on Proportional Resonant Current Control for 7-Level Multilevel Inverter with Reduced Switching Device," 2018 IEEE 4th Southern Power Electronics Conference (SPEC), Singapore, Singapore, 2018, pp. 1-6.

[38] K. K. Gandham, L. Lakshmi, N. Gopichand, "Modelling of PR Controller For A Grid Connected Single Phase Inverter," IJEDR, vol. 5(4), pp.201-207 


\section{BIOGRAPHIES OF AUTHORS}

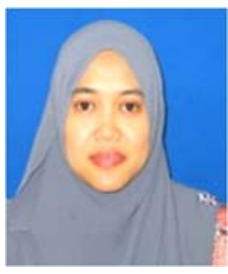

Suriana Salimin is a lecturer in Faculty of Electrical Engineering (FKEE), UTHM. After graduated from her first degree in Eletrical Engineering (UTM-2006), she worked as a tutor in UTHM for 6 months and continued for MSc in Power Distribution Engineering in Newcastle University (2007). She completed her PhD in Electrical Engineering in 2014 also from

Newcastle University, UK. She has published a few papers in Jurnals and proceeding since 2013. Her research interests are on power quality improvement, distributed generation systems, renewable energy and harmonics mitigation.

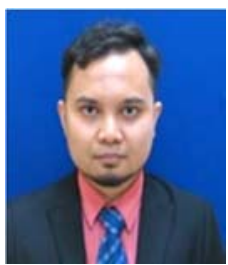

Ahmad Fateh bin Mohamad Nor obtained Bachelor of Electrical Engineering (Power Electronics and Drives) in 2011, Master of Electrical Engineering (Industrial Power) in 2013 and Ph.D. in Electrical Power Engineering in 2017 from Universiti Teknikal Malaysia Melaka (UTeM). Currently he is a lecturer at the Department of Electrical Power Engineering, Faculty of Electrical and Electronic Engineering, Universiti Tun Hussein Onn Malaysia. His area of research interests includes electrical power engineering, voltage instability analysis, solar electricity, artificial neural network (ANN) and adaptive neuro-fuzzy inference system (ANFIS).

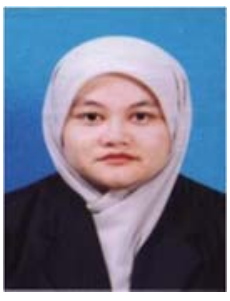

Siti Amely Jumaat was born in Johor, Malaysia on March 12, 1979. She graduated from the Institut Tun Hussein Onn (ITTHO-UTM) with honours degree in BSc. Electrical Eng. in 2001, MEng. (Power), UTM in 2003, and PhD in Electrical Eng at UiTM, Malaysia in 2015. Her research interests include power system and optimization techniques, FACTS devices, Artificial Intelligent techniques and renewable energy system. She is also a member of BEM, IEM, IEEE, and IEEE Power Engineering Society (PES) 2008. 